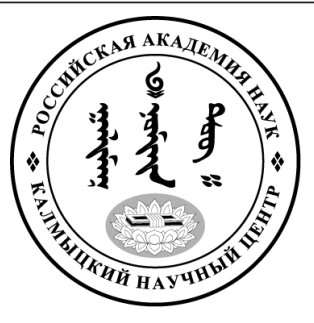

Published in the Russian Federation

Oriental Studies (Previous Name: Bulletin of the Kalmyk Institute

for Humanities of the Russian Academy of Sciences)

Has been issued as a journal since 2008

ISSN: 2619-0990; E-ISSN: 2619-1008

Is. 5, pp. 799-811, 2019

DOI: $10.22162 / 2619-0990-2019-45-5-799-811$

Journal homepage: https://kigiran.elpub.ru

УДК 902/904

\title{
Реконструкция образов «царя» и «царицы» из кургана Аржан-2: особенности, проблемы, пути их решения
}

Роланда Биче-ооловна Ховальг ${ }^{1}$, Шенне Романовна Хорлуштай Аржаана Валерьевна Дамба

${ }^{1}$ Национальный музей им. Алдан-Маадыр Республики Тыва (д. 30, ул. Титова, 667000 Кызыл, Российская Федерация)

главный хранитель

ORCID ID: 0000-0002-6390-7406. E-mail: hovrol@mail.ru

${ }^{2}$ Национальный музей им. Алдан-Маадыр Республики Тыва (д. 30, ул. Титова, 667000 Кызыл, Российская Федерация)

хранитель 1 категории отдела учета и хранения фондов

ORCID ID: 0000-0001-9858-7222. E-mail: shenne.horlushtay@mail.ru

${ }^{3}$ Национальный музей им. Алдан-Маадыр Республики Тыва (д. 30, ул. Титова, 667000 Кызыл, Российская Федерация)

специалист по учету музейных предметов 1 категории отдела учета и хранения фондов

ORCID ID: 0000-0002-8814-4054. E-mail: damba.arzhaana@mail.ru

${ }^{4}$ Национальный музей им. Алдан-Маадыр Республики Тыва (д. 30, ул. Титова, Кызыл, Республика Тыва, 667000, Российская Федерация)

хранитель 1 категории отдела учета и хранения фондов

ORCID ID: 0000-0001-9244-9208.E-mail: oorzhakvera76@mail.ru

Аннотация: Введение. Статья посвящена проблеме реконструкции образов «царя» и «царицы» из погребально-поминального комплекса скифского времени «Аржан-2» (2-я половина VII в. до н. э.) на основе археологических и антропологических исследований. Аржан-2 - памятник мирового значения в «Долине царей» на территории Пий-Хемского кожууна Республики Тыва, национальное достояние народов России. Курган был исследован в 1998-2004 гг. совместной Центрально-Азиатской археологической экспедицией Государственного Эрмитажа во главе с научным сотрудником отдела археологии К. В. Чугуновым и Германского Археологического Института во главе с Г. Парцингером и А. Наглером. Цель исследования — раскрытие особенностей и проблем при реконструкции образов скифских «царя» и «царицы», путей их решения, изучение вклада российских ученых в исследование скифской культуры и анализ деятельности сотрудников Национального музея Республики Тыва по популяризации и сохранению памятников истории и культуры. При исследовании данного памятника скифского времени в Туве остро стояли вопросы происхождения погребенных, периодизации, названия культур, автохтонности, взаимосвязи с культурами ранних кочевников Евразии и в особенности Минусинской котловины, Алтая, Западной Монголии, а также вопросы их антропологического образа 
и внешнего вида. Результаты. В статье представлены история создания образов «царя» и «царицы», результаты археологических и антропологических исследований ведущих российских исследователей, по которым восстановлены внешний прижизненный облик и костюмы «царя» и «царицы».

Ключевые слова: Аржан-2, научная реконструкция, образ, погребально-поминальный комплекс, антропологические исследования, археологические коллекции, скифская эпоха, костюмы, физический облик

Для цитирования: Ховалыг Р. Б., Хорлуштай Ш. Р., Дамба А. В., Ооржак В. Д. Реконструкция образов «царя» и «царицы» из кургана Аржан-2: особенности, проблемы, пути их решения. Oriental Studies. 2019;(5): 799—811. DOI: 10.22162/2619-0990-2019-45-5-799-811.

UDC $902 / 904$

\title{
Reconstructing Images of 'King' and 'Queen' from Arzhan-2 Mound: Features, Problems, Solutions
}

\author{
Rolanda B. Khovalygl, Shenne R. Khorlushtay', Arzhaana V. Damba, \\ Veronika D. Oorzhak \\ ${ }^{1}$ Aldan Maadyr National Museum of the Republic of Tuva (30, Titov St., 667000 Kyzyl, Russian \\ Federation) \\ Chief Custodian \\ ORCID ID: 0000-0002-6390-7406. E-mail: hovrol@mail.ru
}

${ }^{2}$ Aldan Maadyr National Museum of the Republic of Tuva (30, Titov St., 667000 Kyzyl, Russian Federation)

First-Class Custodian, Museum Collection Records Department

ORCID ID: 0000-0001-9858-7222. E-mail: shenne.horlushtay@mail.ru

${ }^{3}$ Aldan Maadyr National Museum of the Republic of Tuva (30, Titov St., 667000 Kyzyl, Russian Federation)

First-Class Specialist, Museum Collection Records Department

ORCID ID: 0000-0002-8814-4054. E-mail: damba.arzhaana@mail.ru

${ }^{4}$ Aldan Maadyr National Museum of the Republic of Tuva (30, Titov St., 667000 Kyzyl, Russian Federation)

First-Class Custodian, Museum Collection Records Department

ORCID ID: 0000-0001-9244-9208.E-mail: oorzhakvera76@mail.ru

\begin{abstract}
Introduction. The article deals with the reconstruction of images of the 'king' and 'queen' from the Scythian burial complex Arzhan-2 (mid-to-late $7^{\text {th }}$ century BC) undertaken through the use of archaeological and anthropological studies. Arzhan-2 is a monument of world significance located in the Valley of the Kings (Piy-Khemsky District, Republic of Tuva) and is a national heritage of Russia's peoples. The mound was investigated in 1998-2004 by the Joint Expedition of the State Hermitage Museum (the branch headed by archaeologist K. Chugunov) and the German Archaeological Institute (the branch headed by H. Parzinger and A. Nagler). Goals. The paper seeks to reveal peculiarities and problems faced during the reconstruction of images of the Scythian 'king' and 'queen', ways of their solution, examines the impact of Russian scientists into the research of Scythian culture, and analyzes activities by associates of Tuva's National Museum aimed to popularize and preserve monuments of history and culture. The investigation of this Tuva-based Scythian monument was associated with a number of critical questions, such as origins of the buried individuals, identification of respective period and culture, indigenousness, relations to other early nomads of Eurasia and especially to those of Minusinsk Hollow, Altay, Western Mongolia, as well as issues of their anthropology and appearances. Results. The article outlines the history of creation of the images of 'king' and 'queen', summarizes results of archaeological and anthropological studies by leading Russian researchers that proved instrumental in reconstructing actual appearances and garments of the 'royal couple'.
\end{abstract}


Keywords: Arzhan-2, scientific reconstruction, image, burial complex, anthropological studies, archaeological collections, Scythian era, costumes, appearances

For citation: Khovalyg R. B., Khorshultay Sh. R., Damba A. V., Oorzhak V. D. Reconstructing Images of 'King' and 'Queen' from Arzhan-2 Mound: Features, Problems, Solutions. Oriental Studies. 2019; (5): 799-811. DOI: 10.22162/2619-0990-2019-45-5-799-811.

\section{Введение}

В экспозиции «Сокровища Долины царей Тувы. Царские курганы Аржан и Аржан-2» Национального музея им. Алдан-Маадыр Республики Тыва (НМ РТ) с 2008 г. экспонируется коллекция золотых изделий скифской культуры, найденных в царских погребениях раннескифской эпохи Аржан и Аржан-2, имеющих мировое значение и являющихся частью национального достояния народов России [НМ РТ]. С тех пор золотая коллекция привлекает в Туву ученых со всего мира, занимающихся проблемами скифологии, и многочисленных туристов - как российских, так и зарубежных.

Погребально-поминальный комплекс раннескифского времени был найден в знаменитой «Долине царей», расположенной в Турано-Уюкской котловине, где сосредоточена цепочка «царских курганов», насчитывающих около сотен объектов.

В 1971-1974 гг. выдающимся советским археологом М. П. Грязновым и тувинским археологом М. Х. Маннай-оолом был раскопан самый крупный курган в «Долине царей» Аржан, памятник раннескифской эпохи, датированный IX-VIII вв. до н. э. (диам. 120 м). В нем в двух колодах были захоронены «царь» и «царица». Вокруг них было захоронено еще 8 человек и 6 коней, всего же в кургане обнаружили могилы 15 человек и 160 коней, сопровождавших «царя» и «царицу» в последний путь. Погребения кургана, к сожалению, оказались разграбленными.

Однако материалы кургана Аржан, датированного рубежом IX-VIII вв. до н. э., стали источником важного научного открытия по археологии всей степной зоны Евразии. Они показали, что в Центральной Азии кочевая культура развивалась задолго до первого упоминания о кочевниках-скифах в письменных источниках, что привело к пересмотру многих уже сложившихся представлений и гипотез [Чугунов, Парцингер, Наглер 2004: 5-6]. Была доказана гипотеза о центральноазиатском происхождении скифской культуры.

Мировой сенсацией 2004 г. стало открытие еще одного кургана «Долины царей» погребально-поминального комплекса Аржан-2. Это один из наиболее крупных курганов, расположенных в «Долине царей» Тувы, которая находится у пос. Аржаан, в центре Турано-Уюкской котловины, к юго-востоку от регионального центра г. Кызыла. Исследовался этот курган с 1998 по 2004 гг. совместной экспедицией Государственного Эрмитажа (г. Санкт-Петербург) и Германского археологического института (г. Берлин). Руководителями раскопок выступили старший научный сотрудник Гос. Эрмитажа К. Чугунов, профессор Г. Парцингер и доктор А. Наглер. Диаметр кургана -80 м, высота - 2 м.

Аржан-2 является захоронением представителей высшего социального слоя населения, жившего на территории Тувы во второй половине VII в. до н. э. Эта дата подтверждена серией радиоуглеродных анализов, выполненных в лабораториях Санкт-Петербурга, а также Германии и других стран [Чугунов, Парцингер, Наглер 2004: 16]. Общее количество предметов, найденных в кургане Аржан-2, насчитывает более 11 тыс. ед.

Памятник относится к культурам скифского типа или скифо-сибирской культурной общности. Скифская (или скифо-сибирская) культура в широком смысле - это культура, распространившаяся в I тыс. до н. э., в начале эпохи железа, на территории степной и лесостепной зон Евразии - от Нижнего Дуная на западе и до излучины Хуанхэ на востоке. Основой этой культуры стало кочевое скотоводство, а показателем единства многие ученые считают так называемую «скифскую триаду» - оружие, конскую упряжь и звериный стиль в искусстве. Все составляющие этой триады действительно встречаются на всей огромной территории [Чугунов, Парцингер, Наглер 2004: 3]. 
Золотые изделия из погребально-поминального комплекса Аржан-2, поражающие высоким мастерством исполнения и великолепным художественным вкусом древних ювелиров, свидетельствуют о высочайшем уровне ювелирного искусства, которое было достигнуто к этому времени жителями Центральной Азии. Эти шедевры древних мастеров навсегда останутся достоянием мировой культуры [Чугунов 2004: 37].

\section{Основная часть}

О вопросах происхождения погребённых в кургане Аржан-2

В связи с открытием двух крупных царских захоронений скифского времени на территории Тувы остро встали вопросы об их происхождении, периодизации, названии культур, которые они представляют, связях с культурами ранних кочевников Евразии и в особенности Минусинской котловины, Алтая, Западной Монголии. Вопросы о происхождении погребённых интересовали не только ученых, но и тувинцев, желавших знать о влиянии скифов на их культуру. Интерес усилился в связи с открытием кургана Аржан, поскольку появились факты, позволяющие говорить об автохтонности скифской культуры и наиболее ранней дате ее появления именно на этой территории [Чикишева 2006: 37]. Людей интересовали вопросы о физическом облике и одежде погребённых, их антропологической принадлежности и связи с современными тувинцами, тем самым поднимался вопрос: являются ли скифы их предками и как выглядели жители Центральной Азии, жившие здесь и оставившие непревзойденную культуру, которую мы можем увидеть по предметам из кургана Аржан-2? Какими были скифы Центральной Азии? Монголоиды или европеоиды?

Интересно, что свое слово, не дожидаясь мнения ученых, уже сказали деятели искусства. Например, известный бурятский скульптор Даши Намдаков изобразил в своей работе «Царская охота» скифских царя и царицу из кургана Аржан-2. В его видении это монголоиды. Скульптурная композиция на скифскую тему принесла российскому художнику мировое признание и награду, престижную международную премию «Пьетрасанта и Версилия», как лучшему художнику 2013 года [Каюмова 2017].
Специалисты Эрмитажа, участвовавшие в раскопках, считают, что обнаруженная ими скифская царская чета - европеоиды и принадлежат к иранской языковой группе. Но предположениям археологов противоречат гипотезы других ученых-скифологов.

Скифы известны в письменных источниках как кочевые народы, которые господствовали в евразийских степях на протяжении всего железного века. Однако их происхождение и точная природа их социальной организации остаются предметом споров. Известно, что в отношении происхождения скифов преобладают три гипотезы, которые можно обобщить как «западное происхождение», «восточное происхождение» и «межрегиональное происхождение».

Так, И. М. Мизиев, один из известных ученых, работавших над теоретико-методологическими проблемами концепции лингвистического обоснования этногенетических связей народов Северного Кавказа и культурного ареала Передней Азии, ссылается на большого знатока истории скифов Ф. Ф. Мищенко. Тот писал, что «наличность в европейской Скифии арийского и частнее иранского элемента установлена убедительно проф. В. Ф. Миллером; только следует искать его не в господствующей части скифского населения Южной России, а в тех зависимых от царских скифов пахарях и каллипидах, которые, будучи оттеснены сюда более воинственными завоевателями, и представляли много общего с сарматами, также, вероятнее всего, принадлежавшими к иранской ветви» [Мизиев 1986: 19].

Мнение Ф. Ф. Мищенко о том, что царские скифы не были ираноязычными, поддержал и другой выдающийся знаток скифов В. В. Латышев. Близки к этой точке зрения и солидарны с ней и ученые Б. Н. Граков и А. М. Мелюкова [Граков, Мелюкова 1952: 50-51]. Прежде чем «списать» эти мысли и предать их забвению как безнадежно устаревшие, необходимо опровергнуть нижеследующие сведения самого Геродота и массу явно тюркских элементов в языке и культуре скифских племен, которые совершенно чужды их ираноязычным потомкам - сарматам и алано-осетинам [Мизиев 1986: 18, 19].

По легенде о происхождении скифов, которую для нас сохранил древнегреческий историк Геродот [Смирнов 1966: 7, 8], можно предположить, что скифы были тюркоя- 
зычным народом. Согласно данной легенде, от сына Таргитая - Липоксая произошли те скифы, которые носят название рода авхатов; от среднего брата Арпоксая - те, которые называются паралатами; общее название всех их - сколоты, по имени одного из царей. Скифами эти племена называли древние греки (эллины).

Эту же мысль подтверждает И. М. Мизиев. Он писал, что «иранисты не только избегают упоминания таких скифо-тюркских личных имен, как „Папай““ („Бабай“ - предок), „Апи“ („Апай“ — мать, матушка), „Атей“ („Ата“ - отец), но и не могут правдоподобно объяснить этимологию имен легендарных скифов - Таргитай, Липоксай, Арпоксай, Колаксай и других, которые имеют весьма прозрачные поныне бытующие тюркские значения» [Мизиев 1986: 22].

Прочитав работу И. М. Мизиева, тувинцы могут поразиться схожести данных имен и слов с тувинскими именами и словами, так как их язык относится к тюркской языковой ветви. Например, тувинское слово авай 'мать' произносится в уменьшительно-ласкательной форме как апай, а слово $a \partial a$ 'отец' похоже на скифское слово ата, также тувинское слово ачей (ачай) 'отец' похоже на скифское слово атей 'отец'. Имена Таргитай, Липоксай, Арпоксай, Колаксай напоминают тувинские Чагытай, Таргытай, Арбаксай, Холасай, Дарылдай, Белекей и т. д.

В легенде упоминается также персонаж по имени Дарий, который шел с походом на царя Таргитая [Смирнов 1966: 7, 8]. Это имя схоже с тувинским именем Дарый или словом дарыц̆ 'быстро'. Суффиксы в именах -сай, -тай, -naй, -кай, -кей в тувинском языке являются уменьшительно-ласкательными.

В своей монографии «Шаги к истокам этнической истории Центрального Кавказа» в разделе «О скифо-тюркских параллелях» И. М. Мизиев пытается доказать тюркское происхождение скифов, основываясь на их языке и культуре [Мизиев 1986: 18]. Его мнение подтверждают другие ученые, в частности А. Н. Аристов, который писал, что «весьма возможно, что часть скифов Геродота и других древних авторов принадлежала тюркскому племени, как полагают многие из новейших исследователей» [Аристов 1896: 400].

Одним из таких исследователей был и Э. Н. Эйхвальд, который приводит много доводов в пользу того, что среди скифов были и тюркские племена. В частности, он писал, что «к скифам причисляемы были нередко и разные турецкие поколения <..> Есть бесчисленные доказательства тому, что под скифами могли разуметь и турецкие племена. Геродот упоминает тюррагетов и турков...» [Мизиев 1986: 18].

В легендах о происхождении скифов у тюркоязычных народов интерес вызывает происхождение скифов-савроматов, возникших от браков между скифами и мифическими амазонками. Но в этом случае важно учесть, что скифы называли амазонок ойорnama, что со скифского греки переводили как «убийца мужчин». Слово, переданное греками как опор, есть не что иное, как общетюркское ойр, йэр, эр, т. е. 'мужчина', 'муж'. В тувинском языке слово эр также означает 'мужчина'. Заслуживает внимания и то, что амазонки, по словам автора III в. до н. э. Филострата, кормили своих детей кобыльим молоком - кумысом, являющимся традиционным напитком кочевников-тюрков [Мизиев 1986: 18], в том числе тувинцев (тув. хыммыс 'кумыс').

Таким образом, можно полагать, что по языку скифы могут быть предками и тюркоязычных народов.

Палеоантропологические исследования костных останков с кургана Аржан-2

Палеоантропология кочевого населения степного пояса Евразии в I тыс. до н. э., благодаря исследованиям отечественных антропологов, изучена достаточно детально. Несмотря на ряд частных дискуссионных вопросов, все исследователи констатируют смешанность антропологического состава скифов на уровне двух рас — монголоидной и европеоидной, а также неизменность соотношения монголоидного и европеоидного компонентов на протяжении скифской и гунно-сарматской эпох.

C палеоантропологическими источниками Тувы работали ведущие российские антропологи Г. Ф. Дебец и В. П. Алексеев, по результатам исследований которых подтверждалось вышесказанное [Дебец 1950; Алексеев 1984]. Предполагалась автохтонность обоих субстратов, генетически связанных с населением эпохи бронзы, и даже рубежа эпох энеолита - ранней бронзы. Выяснилось, что доминирование монголоидного комплекса центральноазиатской расы, 
лежащего в основе антропологического типа современных тувинцев, начинает проявляться не ранее XIII-XIV вв., т. е. может быть связано с эпохой монгольской экспансии. Но автохтонные субстраты как монголоидных, так и европеоидных типов вошли в той или иной степени в состав тувинского народа [Чикишева 2006: 38].

В результате раскопок кургана Аржан-2 отечественная наука получила не только уникальные золотые артефакты, но и уникальный палеоантропологический материал. Костные останки погребенных людей были увезены в Институт археологии и этнографии СО РАН в г. Новосибирске для дальнейшего научного изучения и исследования. Там группой ученых во главе с известным современным российским антропологом, крупнейшим специалистом по антропологии Сибири и Дальнего Востока Т. И. Чикишевой было проведено максимально возможное комплексное антропологическое исследование, включающее краниометрию, одонтологию, остеологию. В результате краниологических и остеометрических исследований, осуществлявшихся по классическим антропометрическим методикам, были определены половозрастные признаки 35 погребённых: 16 мужчин, 13 женщин и 5 детей, половая принадлежность одного взрослого индивидуума осталась неопределенной. Средняя продолжительность жизни взрослых, погребённых в кургане, составляла 33,5 лет. Средний возраст смерти мужчин - 37,7 лет, и он значительно выше, чем средний возраст смерти женщин (29,2 лет). Равное число детей распределилось в двух возрастных интервалах: 0-2 года и 2,5-7,5 лет [Чикишева 2006: 40].

Все погребённые в кургане, независимо от их социального статуса, отраженного в дифференциации могил по их местоположению на могильном поле и атрибутам обрядовой практики, являются носителями единого антропологического комплекса. Этот антропологический комплекс по краниометрическим данным занимает промежуточное положение по отношению к двум антропологическим формациям первого порядка европеоидной и монголоидной. Данное сочетание краниометрических признаков трудно однозначно соотнести с каким-либо антропологическим типом современного населения Южной Сибири, Центральной Азии, Средней Азии или Казахстана.
Одонтологические особенности ранних кочевников Тувы складываются в своеобразные комплексы, совмещающие признаки основных расовых подразделений современного человечества (монголоидов и европеоидов). Этот одонтологический комплекс мог сформироваться в результате метисации в предшествующее время. В целом одонтологический комплекс группы из Аржана-2 можно рассматривать как смешанный, который формировался на основе как минимум трёх источников - базового, характерного для южной евразийской антропологической общности, и одонтологических комплексов североазиатского и западносибирского типов [Чикишева 2006: 44].

По отношению к современному населению такой комплекс не находит себе полных аналогий, но более всего сходен с одонтологическим комплексом, наблюдаемым у представителей южно-сибирского расового типа, в частности у казахов, обских угров (ханты, манси). От современных тувинцев скифов Тувы отличает, прежде всего, высокая концентрация европеоидного маркера [Чикишева 2006: 45].

Это связано с геополитическим движением народов и его последствиями - миграциями групп племен, в результате которых были размыты границы сложившихся в предшествующие эпохи антропологических общностей, и доминирующую роль в расообразовании играл фактор метисации.

В Туве и южных районах Горного Алтая ко времени тюркских каганатов (VI$\mathrm{X}$ вв. н. э.) фиксируется увеличение удельного веса монголоидного компонента. На рубеже монгольского нашествия и сразу после него (XIII-XIV вв.) тувинское население характеризуется морфологическим комплексом центральноазиатской расы, характерным для подавляющей массы тувинцев и в настоящее время.

Научная реконструкция физического облика «царских» особ кургана Аржсан-2

Национальный музей РТ с целью публичного представления останков древних предков тувинцев в экспозиции музея в марте 2014 г. ходатайствовал перед Министерством культуры РТ о финансировании работ по изучению костных останков и реконструкции облика древних скифов по их черепам. В результате этого палеоантропологические материалы кургана Аржан-2 
(три черепа и фрагменты скелетов) были отправлены в отдел археологии Государственного исторического музея (ГИМ) в г. Москве. Зав. отделом археологии ГИМ Н. И. Шишлиной были предложены услуги специалистов по пластической реконструкции из Института этнологии и антропологии РАН им. Н. Н. Миклухо-Маклая. Национальный музей РТ заключил Договор на оказание возмездных услуг № 30-НМ от 21 марта 2014 г. с младшим научным сотрудником ИЭА РАН Р. М. Галеевым. Им вместе с признанным в мире специалистом в области восстановления лица по черепу, доктором биологических наук Е. В. Веселовской была проведена научная реконструкция трех черепов из кургана Аржан-2: «царя», «царицы» и женщины из сопровождающего захоронения (могилы 22), позволившая воссоздать их физический облик.

Ранее проведенное максимально возможное комплексное антропологическое исследование, включающее краниометрию, одонтологию, остеологию, проведенное группой антропологов из Института археологии и этнографии СО РАН во главе с Т. А. Чикишевой, явилось большим подспорьем Е. В. Веселовской и Р. М. Галееву при проведении научной реконструкции [Веселовская, Галеев 2016: 5].

Антропологическая реконструкция внешнего облика по черепу - одно из приоритетных направлений развития в отечественной антропологии. Начиная с работ М. М. Герасимова, выдающегося советского антрополога, археолога и скульптора, доктора исторических наук, автора методики восстановления внешнего облика человека на основе скелетных останков - так называемого «метода Герасимова», и до сегодняшнего дня, реконструкция лица по черепу как научный метод прошла долгий путь развития. В современной антропологической науке указанный метод имеет широкое применение, как в прикладных исследованиях, например, в судебно-медицинской практике, в визуализации антропологического материала в палеоантропологических исследованиях, так и для музейного пространства. В музейном деле в сочетании с археологическими материалами портреты-реконструкции дают более полное, более яркое представление о населении той или иной эпохи [Веселовская, Галеев 2016: 2].
Портретная реконструкция на краниологической основе каждого из трех черепов прошла несколько неотъемлемых этапов работы по методу М. М. Герасимова. Доктором биологических наук Е. В. Веселовской и Р. М. Галеевым проведена огромная научная и творческая работа. Из научного отчета ученых следует, что один из представленных на реконструкцию черепов череп «царя» (погребение 5, скелет 1) принадлежит мужчине 40-45 лет, рост 167170 см. Злокачественное перерождение костной ткани, патологические изменения на правой его стороне говорят, что мужчина умер из-за злокачественного заболевания. Об этом свидетельствуют результаты исследований антрополога из Германии, профессора Геттингенского университета Майкла Шульца [Чикишева 2006: 46]. Повреждения разного характера на скелетах погребенных в кургане Аржан-2 были исследованы этим ученым. Зубы с сильными посмертными повреждениями и наличие злокачественного заболевания и глубоких морщин при реконструкции черепа говорят о старческом его возрасте, а по наличию на них дистального гребня тригонида, наиболее часто встречающегося у монголоидов (у европеидов и негроидов встречается крайне редко), можно отнести его ближе к монголоидной расе.

Из костей посткраниального скелета могла быть измерена только правая малая берцовая. На основе её длины была рассчитана длина тела погребённого, примерно 167-170 см [Веселовская, Галеев 2016].
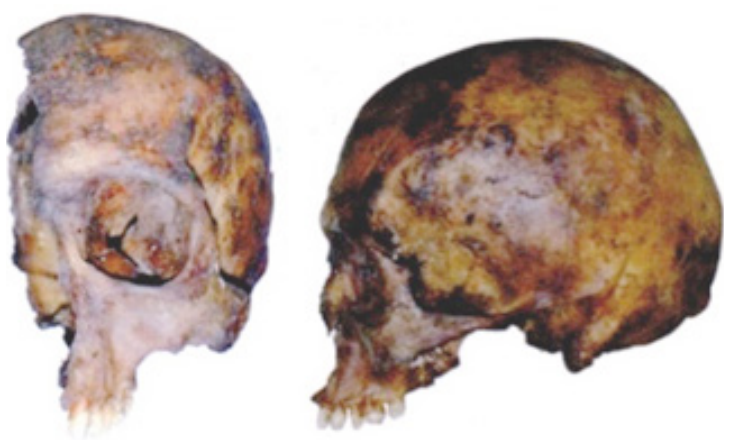

Рис. 1. Череп из погребения 5, скелет 1 («царя») в двух нормах [Fig. 1. Skull in two perspectives. Burial 5, skeleton 1 ('king')] (из научного отчета специалистов по пластической реконструкции черепов ИЭА РАН д. и. н., к. б. н., доцента Веселовской Е. В. и м. н. с. Галеева Р. М. [Веселовская, Галеев 2016: 6]. 
Второй череп из погребения 5 - скелет 2 «царицы», женщины 30-35 лет. Сохранился череп и фрагменты посткраниального скелета. Посмертно разрушены верхняя часть черепной крышки и правая половина нижней челюсти.

К одонтологическим особенностям относятся сочетание лопатообразной формы латеральных резцов верхней челюсти с развитием бугорка Корабелли и затёком эмали на первом и втором молярах. Лопатообразные резцы в одонтологии - характерный признак для большой монголоидной расы.

На основе длины правой малой берцовой кости была рассчитана длина тела погребённой, которая составила около 160,3 см.

Третий череп женщины - из могилы 22 , где находился череп хорошей сохранности с нижней челюстью и полный посткраниальный скелет женщины 25-30 лет. Череп пробит четырьмя ударами чеканов с разной формой бойка (судя по формам отверстий, возможно, это были два разных чекана), характеризующих случай ритуального повреждения черепа [Чикишева 2006: 46]. К одонтологическим особенностям можно отнести раннюю прижизненную утрату обоих центральных нижних резцов. На эмали всех зубов наблюдаются следы гипоплазии - неправильного развития эмали. Чаще всего подобные патологии связывают с неполноценным питанием в раннем детстве.

Для реконструкции черепов производилось дополнительное краниометрическое изучение, определены прижизненные размеры головы на основе усредненных стандартов толщины мягких тканей в различных антропометрических точках. В результате математических расчетов по краниометрическим данным составлены прижизненные портреты для получения обобщенных описательных характеристик облика древних популяций.

В данном случае работа непосредственно на черепах была невозможной в силу большой научной и культурной ценности исходного материала. Поэтому одним из важных и сложных этапов работы являлись получение точных копий черепов и последующая реставрация утраченных частей с использованием специально подготовленного, не маркого, скульптурного пластилина для получения модели с точными размерами.
Учеными использованы два метода для получения 3D-моделей: лазерное сканирование, широко используемый метод в современной науке, и фототригонометрический метод, основанный на компьютерной обработке серии фотографий. Получена была модель с точными размерами. Реставрация производилась твердым скульптурным пластилином и твердой полиуретановой пеной. По окончании всех работ оба материала были удалены.

Далее с пластилиновой модели была снята силиконовая форма и получена гипсовая модель, с которой, в свою очередь, после доработки получена пластиковая копия, используемая для реставрации нижней челюсти.

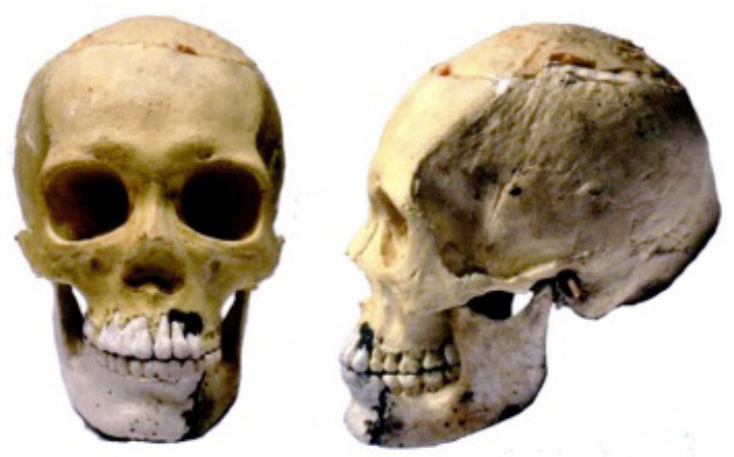

Рис. 2. Результат реставрации черепа из погребения «царицы».

[Fig. 2. Completely reconstructed skull from the 'queen's' tomb]

(из научного отчета специалистов по пластической реконструкции черепов ИЭА РАН д. и. н., к. б. н., доцента Веселовской Е. В. и м. н. с. Галеева Р. М. [Веселовская, Галеев 2016: 33].

В отличие от двух предыдущих объектов череп женщины из погребения 22 сохранился очень хорошо, и какая-либо серьезная реставрация не требовалась, за исключением утраченных передних резцов, клыка и премоляра на верхней челюсти.

Отдельной проблемой при копировании была точная передача дефектов костной пластины (боевых травм) на лобной и теменных костях.

Таким образом, на данном этапе была проделана внушительная работа по сохранению уникального антропологического материала. 
Скульптурная реконструкция внешнего облика

Процесс пластической реконструкции только отчасти напоминает работу скульптора. Скульптор в своей работе ориентируется на готовую модель или серию фотографий, антрополог - на череп, бланки измерений, схемы, чертежи и т. д. Весь смысл работы скульптора-антрополога - это точное воспроизведение схемы головы по краниологическим данным и точное воспроизведение толщин мягких тканей.

Определение возраста по костным останкам - одна из основных задач в физической антропологии. Возраст индивида из погребения «царя» был определен в абсолютных значениях как 40-45 лет (по данным посткраниального скелета чуть шире - 40-50 лет). Это соответствует верхней границе биологической категории matures (взрослый), учитывая патологическое состояние индивида на момент смерти, а именно наличия злокачественной опухоли и других менее значительных патологий, качество и количество воспроизводимых морщин можно отнести ближе к категории senilis (старческий).

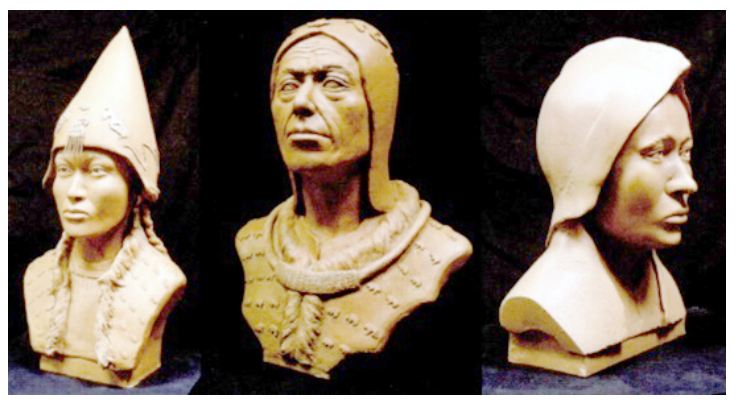

Puc. 3. Финальный этап реконструкции

[Fig. 3. Final stage of the reconstruction process] (из научного отчета специалистов по пластической реконструкции черепов ИЭА РАН: д. и. н., к. б. н., доцента Веселовской Е. В. и м. н. с. Галеева Р. М. [Веселовская, Галеев 2016: 46, 52, 54].

Биологический возраст «царицы» был определен как 30-35 лет, соответствующий когорте matures, учитывая, что антропологический тип был определен с участием монголоидного-уралоидного компонента. Возраст по черепу взрослого человека определяется по нескольким системам, в основном по степени стертости зубов и облитерации швов между костями черепа. То же самое касается и женщины из погребения
22, возраст которой был определен в 2025 лет. Следующим этапом в исторической реконструкции должно стать совмещение в единый образ воссозданного физического облика и одежды древних кочевников-скифов. Заключительный этап реконструкции специалистами оказался самым сложным и трудоемким и нес в себе больше творчества и скульпторской работы, чем научной составляющей.

Необходимо пояснить, что в работе над образом большое значение имеют археологические артефакты (украшения, элементы одежды или воинского снаряжения и так далее), которые напрямую можно связать с погребенным. В случае с Аржаном-2 в погребении «царя» было обнаружено большое количество украшений из золота, бисера, оружия, так что проблема выбора элементов атрибутики не стояла. Более того, в распоряжении специалистов находились реконструкции одежды и украшений, выполненные профессиональными реконструкторами из Института археологии и этнографии СО РАН (Д. В. Поздняков) и Эрмитажа. Результаты реконструкций одежды были несколько различны (что не является ни в коем

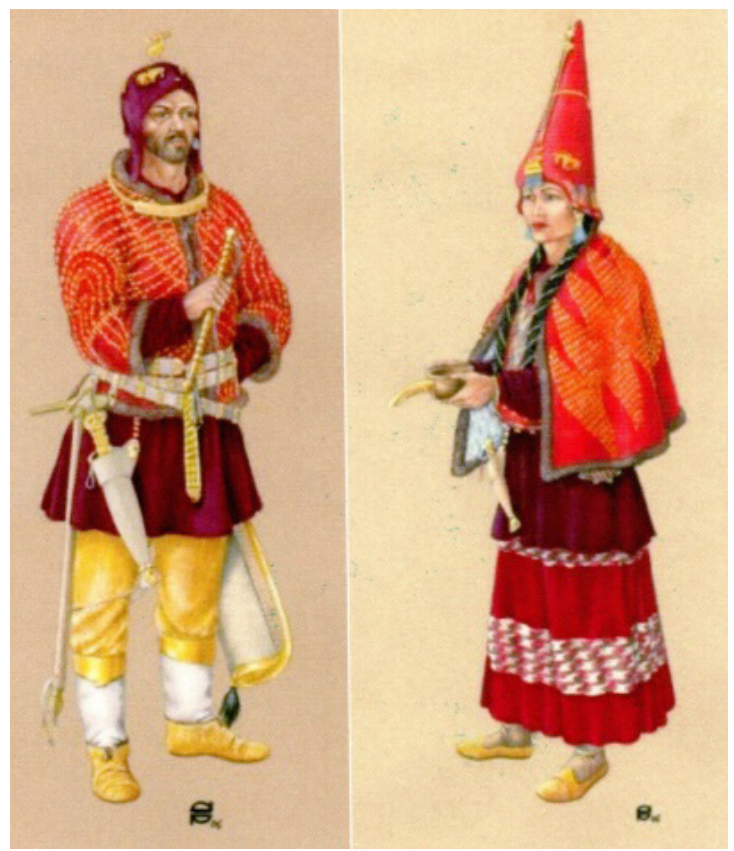

Рис. 4. Реконструкция одежды по Д. В. Позднякову

[Fig. 4. Garments. A reconstruction by D. Pozdnyakov.]

(из научного отчета специалистов по пластической реконструкции черепов ИЭА РАН д. и. н., к. б. н., доцента Веселовской Е. В. и м. н. с. Галеева Р. М. [Веселовская, Галеев 2016: 49]. 
случае показателем разницы профессионализма). Специалисты остановились на реконструкциях Д. В. Позднякова, известного антрополога и признанного профессионала в реконструкциях одежды по археологическим данным. Их выбор был обусловлен как субъективными причинами, так и тем, что данным автором были опубликованы великолепные рисунки, что в их скульптурной работе явилось большим подспорьем.

Полностью или хотя бы в значительной части передать мастерство древних ювелиров (речь идет об уникальных золотых украшениях с большим количеством деталей, выполненных в технике мелкой, а иногда и, уместно сказать, микро-пластики) не получится. Большинство сложных элементов из золота специалистами было стилизовано и упрощено. Конечный вариант был выполнен из высокопрочного полиуретанового пластика. В цветовом решении скульптуры были раскрашены в двух вариантах. В одном варианте под темную бронзу с использованием бронзовой пудры и акриловых красок, в другом варианте скульптуры были покрыты краской, имитирующей светло-бежевую терракоту. Специалисты Е. В. Веселовская и Р. М. Галеев провели сложнейшие работы по научной реконструкции и воссоздали физический облик по черепам царских особ из кургана Аржан-2.

Уникальные работы по реконструкции костюма представителей кочевой «элиты» из погребального памятника Аржан-2 с территории Тувы второй половины VII в. до н. э. были осуществлены сотрудниками Государственного Эрмитажа и их сибирскими и зарубежными коллегами.

Результатом многолетних работ по консервации, реставрации фрагментов костюмного комплекса стала научная реконструкция «археологического» костюма, выполненная с использованием вспомогательных источников - археологических и изобра- зительных. Погребальный наряд знатных представителей кочевников территории Тувы в прошлом, одетых в роскошные парадные одежды с многочисленными нашивными бляхами из золота, экспонировался в музеях России и Германии и имел огромный успех у посетителей.

В Государственном Эрмитаже в 2004 г. была организована временная выставка «Аржан. Источник в Долине царей», на которой демонстрировались предметы вооружения, конского снаряжения, костюма, ювелирные украшения кочевников, обнаруженные в некрополе Аржан-2. Реконструкции мужского и женского костюмного комплекса номадов аржано-майэмирского времени Тувы, вы-

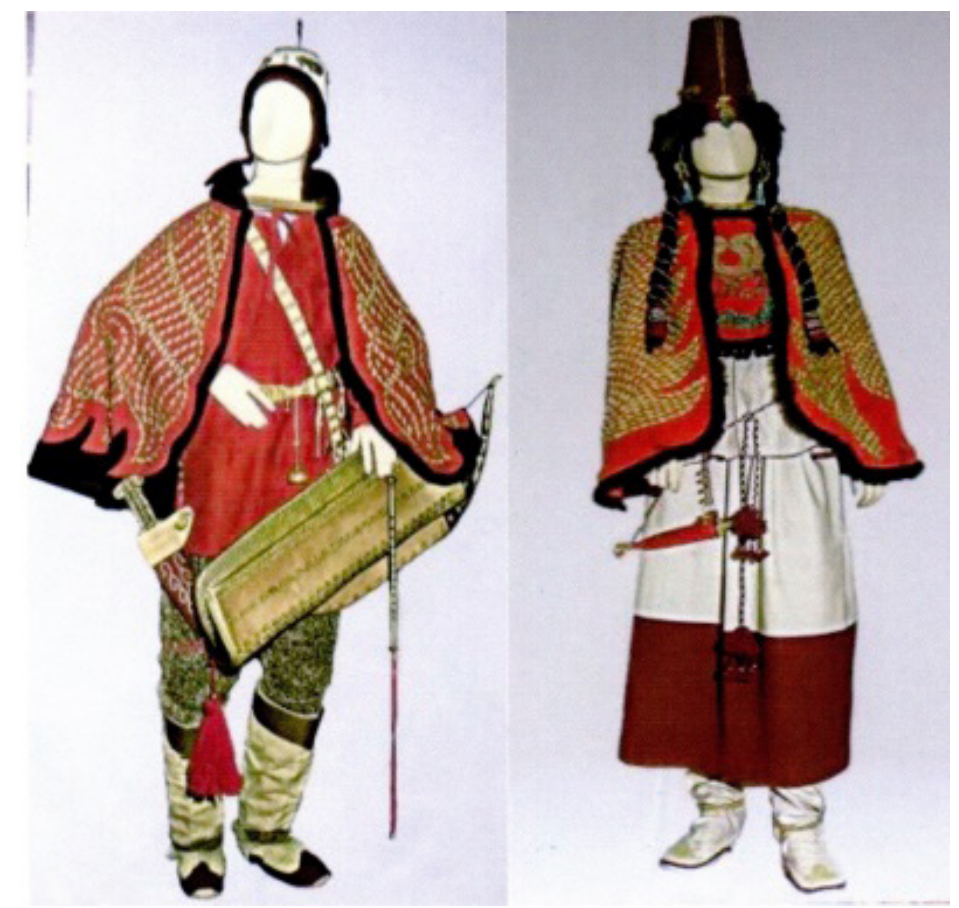

Рuc. 5. Реконструкция одежды «царя» и «царицы», выполненная в Лаборатории научной реставрации произведений прикладного искусства Государственного Эрмитажа (заведующий ЛНРППИ А.И. Бантиков 2004-2005 гг.).

[Fig. 5. Garments of the 'king' and 'queen'. A reconstruction by the Applied Arts Scientific Restoration Laboratory (headed by A. Bantikov, 2004-2005), State Hermitage Museum] полненные Лабораторией научной реставрации произведений прикладного искусства Государственного Эрмитажа (заведующий ЛНРППИ А. И. Бантиков, 2004-2005 гг.), можно увидеть в его постоянной экспозиции. Графические рисунки костюмов из Аржан-2 выполнял Д. В. Поздняков. Его иллюстрации еще раньше позволили предста- 
вить и внешний облик населения пазырыкской культуры Алтая [Усова 2017: 187].

Свои видение и творчество в воссоздании костюмов скифских «царя» и «царицы» также проявил бывший в то время министром культуры Республики Тыва В. О. Донгак - талантливый мастер-модельер по тувинской стилизованной одежде. В настоящее время Национальный музей РТ экспонирует и выставляет на передвижных выставках костюмы «царя» и «царицы», смоделированные В. О. Донгаком, и гальванокопии золотых украшений из кургана Аржан-2, изготовленные знаменитым мастером

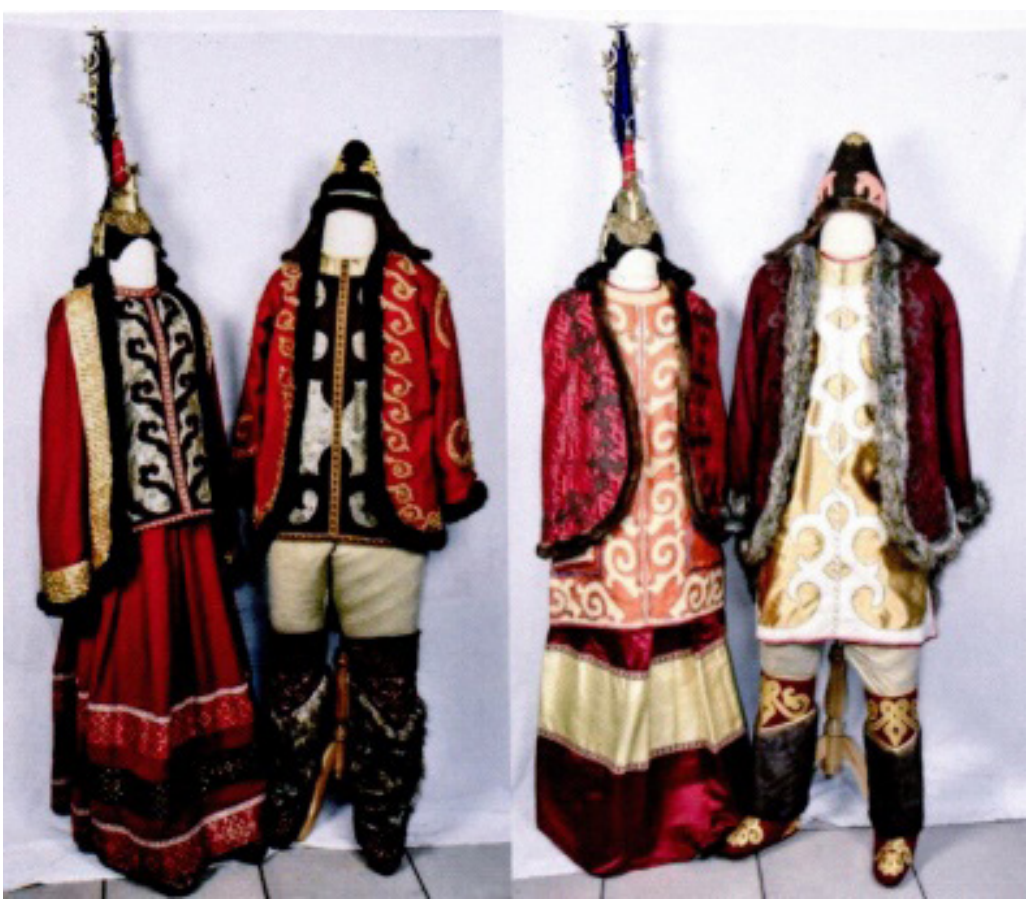

Рис. 6. Реконструкция одежды «царя» и царицы» в 2-х вариантах, выполненных В. О. Донгаком

[Fig. 6. Garments of the 'king' and 'queen'. Two versions. Reconstructions by V. Dongak]

(НМРТ. НВ. №2021\1-13; №2022\1-13. Фото А. Д. Куулар, 2019 г.)

Тувы С. Х. Кочаа.

Нельзя не отметить заслуги в деле организации научного изучения, исследования и воссоздания прижизненного облика «царских» особ из кургана Аржан-2 первого заместителя министра культуры РТ В. С. Чигжита, в то время работавшего директором Национального музея РТ, и заведующего отделом археологии Национального музея PТ О. О. Монгуш. Ими были организованы и проведены все мероприятия по палеоантропологическим исследованиям для воссоздания физического облика погребённых, реконструкции одежды и создания гальванокопий золотых украшений в целях изучения, сохранения и популяризации археологической коллекции кургана Аржан-2. В настоящее время научные реконструкции внешнего облика «царских» особ из кургана Аржан-2 по методу М. М. Герасимова демонстрируются в зале золота в Национальном музее РТ, вызывая неподдельный интерес у посетителей.

\section{Заключение}

Археологи и антропологи с каждым новым исследованием открывают новые страницы истории скифского мира. Т. А. Чики- шева в своей статье пишет: «Аржан-2 - один из самых ранних в ряду элитных курганов, но имеет полный комплекс характерных признаков, маркирующих принадлежность к скифскому миру. В то же время до эпохи скифов мы не наблюдаем активного освоения людьми географического пространства Тувы. Находясь в центре Евразии, в окружении ярких, трансконтинентальных по влиянию на ход исторических процессов культур эпохи бронзы, Тува не дает убедительных археологических свидетельств ее причастности к этим процессам. Как же объяснить демографический всплеск на ее территории в эпоху скифов, как объяснить погребение знатного скифа и его ближайшего окружения в долине Аржаана, в стороне от магистральных процессов кочевого мира Евразии? Являлась ли Тува своеобразным сакральным пространством для скифской знати? Какому племенному объединению это пространство принадлежит? На эти и многие и другие вопросы ученым-скифологам еще предстоит ответить» [Чикишева 2006: 47].

Современный уровень развития науки позволяет найти ответы на эти вопросы. 
Большие надежды она возлагает на молекулярных генетиков, научившихся извлекать наследственный материал из древних костей и анализировать его. Будущие исследования генетиков позволят нам, как пишет Т. А. Чикишева, с достоверностью говорить о родственных взаимоотношениях погребенных, найти в огромном Евразийском регионе наиболее близкие к ним группы давно ушедших людей [Чикишева 2006: 47].

Научные реконструкции внешнего облика древних скифов, демонстрируемые в зале золота Национального музея РТ, были осуществлены с целью формирования инновационной научно-образовательной среды и экспозиционной работы в сфере антропологии и этнологии в музейной деятельности. Благодаря вышеуказанным научным реконструкциям одежды и внешнего прижизненного облика «царских» особ, уникальным археологическим находкам скифского времени, посетители музея получают наглядное представление об искусстве, культуре и быте древних кочевников-скифов.

Таким образом, Национальный музей Республики Тыва в настоящее время рассматривает вопросы дальнейшего «оживления» древних образов. Обсуждается проблема реконструкции физического облика других погребённых людей и лошадей из кургана Аржан-2, т. е. создания целого экспозиционного комплекса, посвященного скифской эпохе.

\section{Источники}

НМ РТ - Национальный музей им. Алдан-Маадыр Республики Тыва. Научно-вспомогательный фонд (HB) №2021\1-13; №2022\1-13.

Веселовская, Галеев 2016 - Веселовская E. B., Галеев P. M. Научный отчет «Реконструкция внешнего облика трех погребенных из могильника скифского времени Аржан 2»// Архив НМ РТ. Ф. № 1. ОП. № 1/1. Д. 681-1. 64 л.

\section{Sources}

Aldan-Maadyr National Museum of the Republic of Tuva. Scientific and Auxiliary Fond No. 2021 \1-13; 2022\1-13.

Veselovskaya, E. V., Galeev, R. M. [Scientific Report 'Three Individuals from the Scythian Burial Ground Arzhan 2: Reconstruction of
Appearances']. At: Aldan-Maadyr National Museum of the Republic of Tuva, Archive. Fond 1. Ser. 1/1. File 681-1. 64 p. (In Russ.)

\section{Литература}

Алексеев 1984 - Алексеев В. П. Краткое изложение палеоантропологии Тувы в связи с историческими вопросами // Антропо-экологические исследования в Туве. М.: Наука, 1984. С. 6-75.

Аристов 1896 - Аристов Н. А. Заметки об этническом составе тюркских племен и сведения об их численности // Живая старина, вып. III-IV, год шестой. СПб., 1896. С. 277-456.

Граков, Мелюкова 1952 - Граков Б. Н., Мелюкова А. И. Об этнических и культурных различиях в степных и лесостепных областях европейской части СССР в скифское время // Вопросы скифо-сарматской археологии. Л., 1952. С. 50-51.

Дебец 1950 - Дебеи Г. Ф. К палеоантропологии Тувы // Краткие сообщения Института этнографии АН СССР. Вып. 10. M., 1950. C. 97-111.

Каюмова 2017 - Каюмова А. Миф, ставший символом Центра Азии // Тувинская правда. 2017. 9 сентября. С. 16.

Мизиев 1986 - Мизиев И. М. Шаги к истокам этнической истории Центрального Кавказа. Нальчик: Эльбрус, 1986. 184 с.

Смирнов 1966 - Смирнов А. П. Скифы. М.: Наука, 1966. 201 с.

Усова 2017 - Усова И. А. Костюм кочевников Центральной Азии и сопредельных территорий I тысячелетия до н. э. в музейной экспозиции как инструмент интерпретации прошлого (по материалам курганов Алтая, Тувы, Казахстана) // Музей - памятник - наследие. 2017. № 1. С. 184-189.

Чикишева 2006 - Чикишева T. А. Палеоантропологические материалы из кургана Аржан-2 // Вопросы изучения истории и культуры народов Центральной Азии и сопредельных территорий: матлы междунар. науч.-практ. конф. Кызыл: Аныяк, 2006. С. 37-50.

Чугунов 2004 - Чугунов K. В. Аржан источник // Аржан. Источник в Долине царей. Археологические открытия в Туве. СПб.: Славия, 2004. С. 10-37.

Чугунов, Парцингер, Наглер 2004 — Чугунов К. В., Паричинер Г., Наглер А. Золотые звери из долины царей. СПб.: Гос. Эрмитаж, 2004. 20 с. 


\section{References}

Alekseev V. P. An outline of Tuva's paleoanthropology in its relation to historical issues. In: [Anthropological Studies in Tuva]. Moscow: Nauka, 1984. Pp. 6-75. (In Russ.)

Aristov N. A. Turkic tribes: notes on their ethnic composition and numbers. Zhivaya starina. 1896. No. 3-4. Pp. 277-456. (In Russ.)

Chikisheva T.A. Paleoanthropological materials from Arzhan-2 mound. In: [Peoples of Central Asia and Adjacent Territories: Issues of History and Culture Research]. Conf. proc. Kyzyl: Anyak, 2006. Pp. 37-50. (In Russ.)

Chugunov K. V. Arzhan - spring. In: [Arzhan. A Spring in the Valley of the Kings. Archaeological Discoveries in Tuva]. St. Petersburg: Slaviya, 2004. Pp. 10-37. (In Russ.)

Chugunov K. V., Parzinger H., Nagler A. [Golden Animals from the Valley of the Kings]. St. Petersburg: State Hermitage Museum, 2004. 20 p. (In Russ.)

Debets G. F. Notes on paleoanthropology of
Tuva. In: [Institute of Ethnography, USSR Academy of Sciences: Collected Brief Reports]. Vol. 10. Moscow, 1950. Pp. 97111. (In Russ.)

Grakov B. N., Melyukova A. I. The Scythian era: ethnic and cultural differences in the steppe and forest-steppe regions of the European part of the USSR revisited. In: [Questions of Scytho-Sarmatian Archaeology]. Leningrad, 1952. Pp. 50-51. (In Russ.)

Kayumova A. The myth that became a symbol of the Center of Asia. Tuvinskaya pravda. 2017. September 9. P. 16. (In Russ.)

Miziev I. M. [Central Caucasus: Approaching the Beginnings of Its Ethnic History]. Nalchik: Elbrus, 1986. 184 p. (In Russ.)

Smirnov A. P. [The Scythians]. Moscow: Nauka, 1966. 201 p. (In Russ.)

Usova I. A. Costumes of the $1^{\text {st }}$ millennium $\mathrm{BC}$ nomads of Central Asia and adjacent territories as a museum tool for interpreting the past (a case study of mounds of Altai, Tuva, Kazakhstan). Museum - MonumentHeritage. 2017. No. 1. Pp. 184-189. (In Russ.) 